\title{
After 1989: The New Wave of Chinese Science
} Fiction

\section{Mingwei Song}

\section{(2) OpenEdition \\ 12 Journals}

\section{Electronic version}

URL: http://journals.openedition.org/chinaperspectives/6618

DOI: 10.4000/chinaperspectives.6618

ISSN: 1996-4617

\section{Publisher}

Centre d'étude français sur la Chine contemporaine

\section{Printed version}

Date of publication: 1 March 2015

Number of pages: 7-13

ISSN: 2070-3449

\section{Electronic reference}

Mingwei Song, «After 1989: The New Wave of Chinese Science Fiction », China Perspectives [Online], 2015/1 | 2015, Online since 01 January 2017, connection on 28 October 2019. URL : http:// journals.openedition.org/chinaperspectives/6618; DOI : 10.4000/chinaperspectives.6618 


\title{
After 1989: The New Wave of
}

\section{Chinese Science Fiction}

\author{
MINGWEI SONG
}

\begin{abstract}
This paper examines the new wave of Chinese science fiction as both a subversion and variation of the genre's utopianism of the earlier age. Wang Jinkang's Ant Life (2007), Liu Cixin's China 2185 (1989), the Three-Body Trilogy (2006-2010), and the short story "The Micro-Era" (1999) are the main texts this paper studies. Their reflections on utopianism speak to the post-1989 changing intellectual culture and political economy. This paper argues that the new wave of Chinese science fiction contains a self-conscious effort to energise the utopian/dystopian variations rather than a simple denial of utopianism or a total embrace of dystopian disillusionment, and this is particularly represented in Liu Cixin's novels. The paper also provides some preliminary thoughts on the vision of a post-human future depicted in Liu Cixin's science fiction.
\end{abstract}

KEYWORDS: Science fiction, new wave, utopia/dystopia, post-humanity, Liu Cixin, Three-Body Trilogy.

\section{Beginnings: $1989 / 2185^{(1)}$}

$\mathrm{D}$ arko Suvin, perhaps the most important literary scholar devoted to science fiction studies, once described science fiction (SF) as "at least collaterally descended from utopia; it is, if not a daughter, yet a niece of utopia - a niece usually ashamed of the family inheritance but unable to escape her genetic destiny." (2) This amusing metaphorical comparison illustrates the two genres' shared intellectual tendency to envision alternatives to reality. Science fiction, which Suvin defines as the "literature of cognitive estrangement," (3) has given a modern look to utopianism in terms of scientific, technological, and social advancement since the early days of the nineteenth century - a century characterised by Industrial Revolution and nationalist movements. But in twentieth-century Western literature, utopianism cast dark, dystopian shadows in science fiction that has increasingly become a forefront literary genre to question modern visions of human progress, the use of science and technology, the institutionalisation of society, and the prospect of a technologised future. Dystopian science fiction that contributed to the rise of anti-utopianism in the West after the World Wars and Stalinism is the rebellious "niece" that Suvin perhaps has in mind, who is ashamed of her utopian heritage - but who cannot escape her genetic destiny, because even the darkest dystopian vision comes from the same subversive pursuit of alternatives to reality that inspired utopianism in the first place.

Suvin's metaphor can also be applied to a historical analysis of the relationship between Chinese science fiction and a certain utopianism mainly based on the prevailing evolutionary thinking and a cultural confidence in national rejuvenation, which began to dominate modern Chinese intellectual culture at the beginning of the twentieth century. Liang Qichao's 梁啟 超 Future of New China (Xin Zhongguo weilai ji 新中國未來記, 1902), an unfinished political novel that outlines a utopian blueprint for a revitalised Confucian China, has often been recognised as the origin of Chinese science fiction. The utopian vision and narrative structure of Liang's novel were essential to the earliest Chinese science fiction novels, such as New Story of the Stone (Xin shitou ji 新石頭記, 1908), New Era (Xin jiyuan 新紀元, 1908), and New China (Xin Zhongguo 新中國, 1910). (4) It can be said that from its inception in the late Qing, Chinese science fiction "was instituted as mainly a utopian narrative that projected the political desire for China's reform into an idealized, technologically more advanced world." (5) The scientific "novum" (6) - submarine, flying car, spaceship, moon colony, or reinvented "sky" (7) - crystallises utopianism in concrete images of a future that is advanced equally in science, morality, and political life. While science fiction suffered long periods of inactivity in twentieth century China, the sweeping utopianism remained a guiding force in revivals of the genre after the late Qing. Science fiction during the socialist period, when it was categorised as a subgenre of children's literature, particularly further strengthened the genre's optimism and ideological correctness. After living through the Cultural Revolution, Zheng Wenguang 鄭文光 and his generation added some dystopian reflections on Chinese politics into the genre, but their experiment was quickly silenced by the government campaign against "spiritual pollution" in the mid-1980s.

Here I identify 1989 as the year when a new paradigm of science fictional imagination began to complicate, if not to deny or be ashamed of, the

1. This essay continues to present my reflections on the utopian/dystopian visions in contemporary Chinese science fiction, which I began to discuss in "Variations on Utopia in Contemporary Chinese Science Fiction," Science Fiction Studies, Vol. 40, No. 1, 2013, pp. 86-102.

2. Darko Suvin, Metamorphosis of Science Fiction: On the Poetics and History of a Literary Genre, New Haven, Yale University Press, 1979, p. 61.

3. Ibid., p. 4

4. Wu Jianren, Xin shitou ji (New Story of the Stone), Guangzhou, Huacheng chubanshe, 1987; Biheguan Zhuren, Xin jiyuan (New Era), Nanning, Guangxi shifan daxue chubanshe, 2008; Lu Shi'e, Xin Zhongguo (New China), Beijing, Zhongguo youyi chuban gongsi, 2009. For a detailed account of the history of utopian fiction (including science fiction) in both the Western and Chinese contexts, see Douwe Fokkema, Perfect Worlds: Utopian Fiction in China and the West, Amsterdam, Amsterdam University Press, 2011.

5. Mingwei Song, Preface to "Chinese Science Fiction: Late Qing and the Contemporary," Renditions, Vol. 77/78, 2012, p. 7.

6. Again, this is Darko Suvin's concept that refers to novel things that create the estrangement in science fiction.

7. The reinvented sky is mentioned in Wu Jianren's New Story of the Stone, op. cit. 
utopianism that had dominated Chinese politics and intellectual culture for more than a century. What served as the larger political/cultural backdrop for the changes in Chinese science fiction (and in perhaps all of Chinese literature) were the collapse of idealism and optimism as well as a pervasive disillusionment with communism - or, in general, a political utopianism instituted by the state - after the tragic end of the 1989 democracy movement in Tiananmen Square. One unique science fiction novel, the first of its kind, was written in the spring of 1989, and it signalled the arrival of a new wave in Chinese science fiction, which is more sophisticated, reflective, and subversive in terms of mixed representations of hope and despair, utopianism and its dystopian reflection, and nationalism and cosmopolitanism.

Liu Cixin 劉慈欣 (b. 1963), a young computer engineer who wrote this novel, later became China's most celebrated science fiction writer, with an unrivalled publication record and all the major Chinese SF awards. But his first novel, China 2185 (Zhongguo 2185 中國 2185), which he began to write in February 1989, has only been circulated on the Internet and has never been published in book form. ${ }^{(8)}$ Without any straightforward reference to the student movement on the square, the novel nevertheless begins with a scene in Tiananmen Square: a young computer engineer crosses the deserted square on a dark night and approaches the Mao Mausoleum that still exists in 2185. He manages to scan Mao's dead brain cells and turns the simulated consciousness of the great man into a cybernetic existence.

Combining political fantasy with science fiction, China 2185 describes the resurrection of Mao and five other dead old men's consciousness in cyberspace, where it triggers a cybernetic popular uprising that paralyses the authorities in the real world. The government of China in 2185 has no choice but to shut down the entire Internet, so the cyber-republic, called "Huaxia Congheguo 華夏共和國," quickly sees its own demise. It turns out that Mao's cybernetic existence is not, as one would have thought, the cause of the revolution, which has actually been launched by an ordinary old man's consciousness that replicates itself millions of times and quickly builds a utopian society that lasts for 850 years - in virtual reality, which is equivalent to only two hours in reality. After the republic is wiped out, when all the democratic outcries in the cybernetic uprising die out, the novel ends with a conversation between Mao's cybernetic spectre and the young female leader of the Chinese government: Mao's "ghost" honestly tells his future successor that any attempt for immortality is futile, for "immortality is mortality" (yongsheng jiu shi yongsi 永生就是永死); he appears to be at ease with his own eventual farewell to revolution. In this novel, Liu Cixin does not seem to either glorify the cybernetic uprising or discredit Mao's political legacy, but instead he concentrates on experiments of conceiving "alterity" for the future of humanity, which is not only "post-Mao" but also "post-human."

China's first political cyberpunk novel, China 2185 creates a dynamic utopian/dystopian variation reflecting on democracy, governance, and revolution in new terms informed by cybernetic technology. Its distance from utopianism is obvious, but neither is it a dystopian novel as defined by the genre's Western classics such as 1984, which presents a pervasive criticism of totalitarianism. Liu's novel does not portray an ideal society, and the future society it depicts is actually split into two conflicting parts: the "real" world and the "virtual" nation. The novel holds social criticism at bay while questioning the technological constructs of political consciousness, (cybernetic) subjectivities, and social revolution, and the novel ultimately questions what is "humanity," as defined by technology, when it depicts the splendid rise and fall of the Huaxia Republic as a virtual community of intercybernetic subjectivities.
China 2185 can be identified as the first work of the new wave of Chinese SF that contains a self-conscious effort to energise utopian/dystopian variations rather than serving as a simple denial of utopianism or a total embrace of dystopian disillusionment. Utopianism and its dystopian variety have rather been presented in a complex entanglement in the new wave SF that opens up to new possibilities in restoring imagination in the cultural politics of contemporary China.

\section{The new wave of Chinese SF}

I have borrowed the concept of the "new wave" from Anglo-American SF history to point to the subversive, cutting-edge literary experiment that characterises the works of those new authors who have become the main voices in Chinese science fiction since the beginning of the twenty-first century. I include Liu Cixin in this group, though other critics tend to name him a "neoclassical" or Golden Age SF writer, ${ }^{(9)}$ for his epic style may remind us of the space opera novels of the American Golden Age SF: Liu's Three-Body Trilogy (Santi 三體, 2006-2010) is considered comparable to Isaac Asimov's Foundation series. I have two reasons for arguing against this categorisation of Liu Cixin as a classical Golden Age SF writer: first, Liu's science fictional imagination has obviously outgrown the formulas of a space odyssey set for adventure and conquest; second, Liu's writing style is at the same time sublime and uncanny, with rich references to cybernetic or post-human images against the grandiose canvas of the universe.

Other major writers who belong to the new wave include at least Han Song 韓松 (b. 1965), La La 拉拉 (b. 1977), Zhao Haihong 趙海虹 (b. 1977), Chen Qiufan 陳楸帆 (b. 1981), Fei Dao 飛気 (b. 1983), and Xia Jia 夏笳 (b. 1984). Wang Jinkang 王晉康 (b. 1948), a veteran science fiction writer, has also written several novels and stories on darker, more subversive "new wave" themes, such as the short story "The Reincarnated Giant" (Zhuansheng de juren 轉生的巨人, 2006), which, published unusually under a pseudonym, presents a grotesque allegory of China's uncontrollable desire for development. ${ }^{(10)}$

In another essay I wrote on the new wave of Chinese science fiction, I have discussed the utopian/dystopian variations of three motifs: China's rising as a one-nation utopia; the myth of China's high-speed development; and the post-human utopia of technologies. ${ }^{(11)}$ In the science fictional representations of all three motifs, prosperity begets apocalypse; the utopian vision of China's ascendency to a superpower as promoted by the government has often been shown with nightmarish and inhuman social and ethical effects.

One good example that can explain the subversive nature of the new wave of Chinese SF is Han Song's short story "Regenerated Bricks" (Zaishengzhuan 再生磚, 2010). (12) It presents a ghostly, grotesque vision of China's rapid transformation into a prosperous nation marked by its post-human technologies. The inspiration for this story was the 2008 Sichuan earthquake, which cost nearly 70,000 lives. In Han Song's story, the disaster became the

8. The text is available at kehuan.net (accessed on 26 August 2014).

9. Wu Yan and Fang Xiaoging, "Liu Cixin yu xin gudianzhuyi kehuan xiaoshuo" (Liu Cixin and the new classicist science fiction), Journal of Hunan University of Science and Engineering, Vol. 27, No. 2, 2006, pp. 36-39.

10. An English translation of this story by Carlos Rojas appears in Renditions, Vol. 77/78, 2012, pp. 173-209.

11. Mingwei Song, "Variations on Utopia in Contemporary Chinese Science Fiction," art. cit.

12. The story was published in Wenyi fengshang, December 2010, pp. 59-71. 
opportunity for the success of a so-called "China Model" in a new type of architecture built through recycling the ruins of the earthquake. The mingling of human remains with construction materials leads to the invention of "regenerated bricks" that have artificial intelligence. New civilisations emerge when the A.I. bricks are sent to outer space as construction materials for human colonies on other planets. While human progress, not just China's, is spurred on by this landmark invention, it is forever haunted by the whispers and weeping of the dead. In Han Song's science fictional vision, the future of a new China, as the popular motif that has characterised the genre from the beginning, may still exist, but its "golden era" has become complicated by the dystopian narrative of its success story.

\section{The spectre of Mao in science fiction}

On the other hand, the new wave of Chinese SF has not completely discarded the heritage of utopianism from, specifically, Mao's age. In a highly symbolic way, the new wave began with the cybernetic resurrection of Mao in China 2185. Not a typical SF monster, Mao's cybernetic ego is dangerous enough to cause panic for the future leadership of the Chinese government. The formidable spectre of Mao stands for diehard utopianism, which can be used to convey a potentially subversive message about the alternative to reality.

Wang Jinkang, Liu Cixin, and Han Song, China's "Big Three" in science fiction, all lived through the Cultural Revolution. None of them openly claims to admire Mao, but Mao's spectre often follows their characters in scientific experiments or space odysseys. The eldest of the "Big Three," Wang Jinkang, was once a sent-down youth. One of his most successful novels, Ant Life (Yisheng 蟻生, 2007), draws upon experiences from his life in the rural area and reflects on the Cultural Revolution and particularly Maoist utopianism.

It begins with some pastoral descriptions of youths' lives in an isolated small village, but the plot soon thickens through shifting the narrative's focus to a mysterious experiment that one of the educated youths, Yan Zhe, is working on. An ambitious young scientist, Yan Zhe shares with Mao the utopian impulse to make a revolution in "the most profound place of people's soul." His remedy to "cure" the corruption of humanity is altruism, which he recognises as the key to the success of the species in the seemingly well-organised society of ants. He secretly extracts the so-called "altruistic element" from ants and sprays people - local villains, his fellow students, and finally everyone in the village. In a few days, Yan Zhe makes the village an isolated "utopia" - a community that thrives on altruism. His utopian experiment seems to have worked; villains turn into good people and everyone becomes unselfish, working for the community equally and willingly.

The narrative unfolds from the limited perspective of Yan Zhe's girlfriend Qiuyun and deliberately separates his utopian experiment from the rest of China. Nevertheless, readers cannot overlook the fact that China went through an enormous utopian experiment engineered by Mao at the same time, of which Yan's experiment might well serve as a microcosm. The novel quotes an African visitor's praise for China during the Great Leap Forward; the visitor is surprised by the efficiency of Chinese workers and says, "Western propaganda always depicts the Chinese people as 'blue ants' without independent thinking, forced into labouring under ruthless whipping, which is the most shameless lie and denigration!" (13) Nationalist pride, combined with his strong interest in a biological version of communism, a scientifically practicable altruism, urges Yan Zhe to carry out his experiment with the best wishes for creating a paradise on Earth.
But Ant Life is not a utopian novel. Expectedly, something goes wrong with the experiment intended to do good to humanity. The quick transformation of the villagers to ant-like people is nevertheless a flawed experiment, for the ants need a queen or king or a dictator for their absolutely altruistic community. The ideal society based on ant life naturally becomes hierarchical, while the loss of individual subjectivity in the villagers eventually leads to the ruthless killing of members belonging to other groups of ant-like communities, which leads one to question the universality of "justice" and "equality" when altruism is limited to Yan Zhe's own community. Yan Zhe's utopian community quickly collapses when he abandons the experiment and eventually disappears. Years later, when Qiuyun revisits the site of the community, her husband gives some thoughts on Yan's experiment:

Even if altruism can be achieved on the individual level, he (the husband) does not believe in the "collective" built by all those "good individuals." He is averse to that sort of institution - where a single god, the only one who is clear-minded and works around the clock, herds a group of ant-like people happily daydreaming. He does not want to be one of these people, or the god. That fellow named Yan Zhe did say something right: "There is no reliable mechanism that can consistently keep producing gods who are always good-hearted and selfless." Well said! A clear mind! But he (Yan Zhe) deliberately went against the way and played a role beyond his capacities. ${ }^{(14)}$

Like Mao's Cultural Revolution, Yan Zhe's experiment with altruism results in the most ruthless form of dictatorship. But in Ant Life, Wang Jinkang also tries to reflect on the utopian impulse universally found in people rather than only the political heritage of Mao. Does one want to be morally good, altruistic, and unselfish? What are the conditions for constructing a society where one lives morally? What are the ethical and, indeed, political effects of "reengineering" people morally and politically? What makes the novel more intriguing, if not more ambivalent, is that Yan Zhe is shown as reluctant to make self-reflection on his own utopian idealism. He admits to the failure of his experiment, but he does not consider his principles wrong he never doubts the moral necessity of practicing altruism. The author's judgment over utopianism hinges on intriguing balances between the individual will and institutional mechanism, between technological engineering and human nature. For a moment, Yan Zhe has his triumph, for he herds his people like a good-hearted god; but he cannot remain an infallible god.

The novel's moral lesson, if there is one, is not just a repetition of the story about the evils of dictatorship. It also points to the ethical effects of being either unselfish and submissive to the collective, which is so pervasively depicted as utopian but improbable, or being selfish and individualistic, which is presented in the unpleasant depiction of China's reality. The last part of the novel begins with this quotation: "Because we admire the altruism of ant society, and because we can always make reflections on our own depravity generation after generation, it means - altruism is deeply rooted in our nature." (15) All the characters except Yan Zhe have lived long enough to experience the long post-Mao reform years when the selfishness of people propels society toward accumulating more wealth, together with more inequality and difference in the social hierarchy.

\footnotetext{
13. Wang Jinkang, Yisheng (Ant Life), Fuzhou, Fujian renmin chubanshe, 2007, p. 29

14. Wang Jinkang, Yisheng (Ant Life), op. cit., p. 243.

15. Wang Jinkang, Yisheng (Ant Life), op. cit., p. 224.
} 
Although Ant Life reflects rather negatively on the Mao fad, the spectre of Maoism, incarnated in the utopian urge for equality and justice, is still alive in the science fictional imagination of what is human nature.

\section{The immoral universe of the Three-Body Trilogy}

Mao also plays a role in Liu Cixin's magnum opus the Three Body Trilogy, in which a Mao-like great leader personally launches a secret mission searching for extraterrestrial intelligence, which eventually brings the space war to planet Earth. The Mao-like leader's appearance is brief in the novel, ${ }^{(16)}$ but in a broader context, Mao's revolution serves as the background for the entire plot of the Three-Body Trilogy. The online version of its first volume, The Three-Body Problem, opens with Red Guards' public humiliation of an astrophysicist, which leads to his daughter Ye Wenjie's total loss of faith in human morality. ${ }^{(17)}$ Yet, Ye Wenjie later joins Mao's mission to look for E.T. When she has finally received signals from a hostile alien civilisation, she does not hesitate for even a second to invite them to invade Earth, a decision that echoes her mixed feelings about the Cultural Revolution. Misanthropy combined with hope for a violent purge of all the evils of humanity transforms her into a charismatic leader of an underground movement that prepares for the arrival of alien starships. However, contrary to her own wish to consider the aliens morally more advanced, she is the one, ahead of all the other characters, who discovers the darkest secret of the universe: universal hospitality does not exist at all, while a permanent struggle between "intelligent" beings, like the permanent revolution Mao called for, has been carried on since the moment the universe came into existence. The space war is destined to last until the end of time and space. Ye Wenjie looks at the setting sun for the last time: she sees it as the sunset of humanity, which ends all hope for human survival in an immoral universe. ${ }^{(18)}$

This is only the beginning of the saga. With three volumes published over the span of four years, the Three-Body Trilogy sealed Liu Cixin's reputation as China's foremost science fiction writer. The last volume of the trilogy was on the bestseller lists of China's major newspapers and became the topic of nationwide discussions on TV and the Internet. With a total length of 880,000 characters, the trilogy tells an epic story that begins with the Cultural Revolution and concludes with the end of the universe. The title of the trilogy refers to a problem in physics and classical mechanics, based on which Liu creates a world of Trisolaris in our sun's nearest neighbouring star system, Alpha Centauri, where, as Liu describes imaginatively, the irregular movement of three "suns" renders the only planet of that star system inhabitable for the alien "Trisolarans," as they are called by the Earth humans. The extremely harsh conditions confronting the Trisolarans force them to seek a new habitable planet. Ye Wenjie's invitation thus sets in motion a chain of events that eventually brings a fierce space war to our solar system.

In post-War (and post-Stalin) Western science fiction, it is an overwhelmingly popular motif that the utopian has irreversibly become Orwellian, in which the institutional oppression of the individual, on the one hand, represents the arch-evil of the twentieth century; and on the other hand, the individual heroes' battles with totalitarianism in one way or another represent a belief in the integrity of individuality in spite of institutional corruption. However, in the Three-BodyTrilogy, the Orwellian is not considered evil, and heroes are those who are willed for self-sacrifice. A "collectivist dictatorship" sometimes prevails in the narrative framework of the conflict with the Trisolarans. The spectres of collectivism, communism, and Maoism particularly linger in what Liu Cixin describes as the "starship civilisations," which may look like the true equivalent of Utopia on the surface: isolated "islands" in the ocean of stars, extremely well-organised societies that can automatically operate without the intervention of individuals. But a further twist of the utopian/dystopian dialectics shows that none of these "starship civilisations" is a paradise for humans. An extremely hostile universe forces the "starship citizens" to prioritise survival to such an extent that collectivism legalises cannibalism, which Liu's characters nevertheless defend as necessary to sustain the "civilisation" that has, however, already become inhuman. ${ }^{(19)}$

In the second volume of the trilogy, The Dark Forest, Liu Cixin creates the character Zhang Beihai, the founder of one of the first "starship civilisations." After a simple Trisolaran weapon, nicknamed "the water drop," destroys nearly all the human starships as well as the last hope for humanity to survive its confrontation with the unfathomably advanced alien invasion, Zhang's starship flees the battlefield near Jupiter and leaves the solar system forever. He is the first architect of a new type of civilisation that must confront post-human uncertainty in a totally hostile environment with rather limited resources. In the beginning, the officers of the starship have a debate over how to constitute the new civilisation. While the majority opinion is to keep the military dictatorship, Zhang Beihai says absolutely no; and when others suggest democracy as an alternative, Zhang Beihai hesitates, saying: "Facing a disaster like the encounter with the Trisolaran menace, a society built upon principles of humanism is fragile, especially when our world needs the sacrifice of a part of it for the good of the whole." (20)

Zhang hides his defeatism deeply in his heart. He does not believe that humanity will survive this treacherous space war. He rather believes that only the sacrifice of part or perhaps most of humanity is the condition for the eventual survival of the species, even when it is no longer a civilisation. Zhang Beihai does not lament his own death or the destruction of the starship he leads when another starship attacks it for the purpose of obtaining supplies from it - including the nutrition extracted from the human bodies. Both Liu Cixin and Han Song write about cannibalism. Han Song takes it as a cultural metaphor for social evil, as Lu Xun did, though with an even more grotesque obsession with the anatomical details. (21) But Liu Cixin openly talks about cannibalism as a necessary step for the survival of the species under certain extreme circumstances, (22) a step certainly necessary for the development of the "Starship Civilisation." The members of the "starship civilisation" captured by the Earth humans in the third volume of the trilogy are charged with committing cannibalism, but the defender explains what is the bottom line of morality when lacking all the essential resources

16. In the published version, Mao's name disappeared from the text. Instead, the name of the leader is presented as three blank blocks. In the English translation, it is presented as XXX.

17. This opening is later moved to a later part of the narrative in the printed version. However, the English translation of The Three-Body Problem restores the narrative order of the online version, which begins with three chapters about the Cultural Revolution. Liu Cixin, The Three-Body Problem (translated by Ken Liu), New York, Tor, 2014.

18. Liu Cixin, The Three-Body Problem (English version), op. cit., p. 390.

19. Liu Cixin, Sishen yongsheng (The Dead End), Chongqing, Chongqing chubanshe, 2010, pp. 85-87.

20. Liu Cixin, Sishen yongsheng (The Dead End), op. cit., p. 405.

21. Such grotesque cannibalism can be found in Han Song's novella "Meinü shoulie zhinan" (The guide to hunting beautiful women), which was for the first time published, after having been only available on the Internet for many years, in his recent short story collection Yuzhou mubei (The Tombs of the Universe), Shanghai renmin chubanshe, 2014, pp. 275-373.

22. In a conversation with the historian of science, Professor Jiang Xiaoyuan, Liu directly challenges jiang to answer the question of whether they should eat the moderator of the conversation if they had to do it for survival. Jiang argues for humanism, but Liu presents his absolute preference for survival over civilisation. See Liu Cixin tan kehuan (Liu Cixin on Science Fiction), Wuhan, Hubei kexuejishu chubanshe, 2014, p. 42. 
for life. The cannibals are executed, but the true punishment is not a moral one in Liu Cixin's narrative. The position Liu Cixin lets his character take when facing moral indictment is based upon a post-human understanding of the sacrifice of self and the futility of humanist subjectivity. In another story by Liu Cixin, the entire human race is wiped out when an alien species exploits all the resources from the Earth. The last standing soldiers lie down on the ground, dying peacefully with a faint hope that the nutrition from their bodies will at least enable small insects to survive so that the Earth may not be a completely dead world. (23) Liu is obviously not a humanist, and his concerns with the fate of humanity are stuck in a deadlock conflict between development and morality, or universe (as a moral vacuum for infinite development of intelligence) and humanity.

To prepare for the release of the English translation of the trilogy's first volume, The Three-Body Problem (translated by the Chinese American science fiction writer Ken Liu), Liu Cixin shared some of his own thoughts on the novel with English readers. He says: "Science fiction is a literature of possibilities. The universe we live in is also one of countless possibilities. For humanity, some universes are better than others, and Three Body shows the worst of all possible universes, a universe in which existence is as dark and harsh as one can imagine." (24) The worst of all possible universes is a place where every civilisation is a hunting tribe set out to eliminate rivals. The only solution to survival is to avoid exposing oneself. Liu's statement without a doubt presents the Three-Body trilogy as the darkest possible dystopian novel.

The plot of the trilogy centres on the question of whether morality is possible in a universe that thrives by the law of the jungle. Filled with sublime and awe-inspiring images of space wars, technological utopia, and wondrous mutations of physical rules, Liu Cixin's narrative is cold-bloodedly realistic in portraying the moral dilemma of its characters when confronted with catastrophic threats from much more advanced alien civilisations. A dramatic conflict unfolds between the moral instincts of humanity and the necessity for survival. While a few characters choose to follow the former at crucial moments in the story, the latter prevails in a universe with limited resources, such as the members of the "starship civilisation" that feed on the dead bodies of their comrades.

Ye Wenjie's disciple, Luo Ji, the main character of the trilogy's second volume, establishes the principles of "astro-sociology," which combines social Darwinism with the Maoist mandate for self-defence and pre-emptive attack. Thus Luo ji finds the key to human survival in the moral vacuum of the universe. A well-coordinated defence system is established, which will expose the locations of both the Earth and the home planet of the attacking alien civilisation so that some even more highly intelligent creatures will certainly destroy both. Trisolarans' military advancement is stopped by Luo ji's threat of mutual assured destruction. Civilisations on Earth flourish, and a post-apocalyptical age of decadence begins to emerge in a world that lives on a thin thread of hope. However, the end comes completely unprepared for: a single small spacecraft carrying unknown creatures swiftly flies by the outer edge of the solar system and randomly sends a tiny object toward the sun. The object, thin as a piece of paper, makes anything it contacts two-dimensional; called a "dual-vector foil," it turns out to be the most dangerous weapon in the universe and has been used by a superior god-like civilisation to keep lowering the number of dimensions in the universe from eleven to ten to nine and all the way down to three, and now to two, so that any living creatures adapted to a higher dimensional universe die like fish thrown on dry land.
Liu Cixin depicts in minute detail the two-dimensionalisation of the entire solar system: planet by planet, object by object, molecule by molecule. Saturn, Jupiter, all the small planets, Venus, Mars, Moon, the Earth and human beings, and the Sun and everything all drop into the two-dimensional dualvector foil. The world becomes an enormous flat picture: the most wondrous scene of the entire trilogy. ${ }^{(25)}$ It proves one thing for the characters: the universe is fundamentally immoral; it cannot be darker. Changing physical rules brings not only the demise of rivals but also inevitable mutual assured destruction. Even the superior god-like creatures become victims of the decreasing dimensions of the universe.

Foregrounding the destiny of an incredibly dystopian future, Liu's narrative sometimes remains ambiguous with regards to the conflicts between morality and survival, humanity and technology, hope and despair. Liu makes it clear through the overall plot development that the universe is a cold place with little room for morality. However, the most magical power of the trilogy may still come from the sustained humanity that can be found even in the coldest moments and places. One of the only two persons who live until the end of the universe is Cheng Xin, a kind-hearted woman, who is sarcastically nicknamed the "saint mother" by Liu Cixin's fans to show their dislike of this character who succeeds Luo ji to become the chief defender of the Earth but submits to the tender feelings that swells in her heart when facing the alien invasion. She does not have the heart to push the buttons that will set off the assured mutual destruction of both the invading Trisolarans and all species on Earth. Her failure to act nevertheless makes her morally self-conscious. Against the backdrop of life-and-death struggle, Cheng Xin remains a person constantly reminding us of the moral principles of compassion and mutual aid. She makes a moral choice in an immoral universe. But she also plays an even more important role in the making of Liu Cixin's saga: she resorts to writing to pass on messages about humanity to the next universe. Liu Cixin ends the novel from Cheng Xin's perspective and renames the trilogy "Remembrance of Earth's Past" (Diqiu wangshi 地球往事).

The ending paragraph of the novel, only around 200 characters long, is an enchanting description of a small "ecological system" left by Cheng Xin in "our universe" that has come to an end, in which a small fish swims swiftly and the morning dew on grass reflects the fresh sunshine. Is this where a new universe begins? Or is it a testament to poetic justice? The small ball that contains this lively ecological system may well be the last trace of a utopian space in the moral vacuum of the universe in Liu Cixin's space saga.

Seen from outside the narrative frame of the "Remembrance of Earth's Past," all the words, all the literary descriptions, and all the narratives in the three novels can also be viewed as a testament to poetic justice for human morality that cannot survive in an immoral universe. Like "The Poetry Cloud" (Shiyun 詩雲, 2003), an earlier short story by Liu Cixin, which depicts how a god-like alien creature that ruthlessly destroys the entire solar system becomes obsessed with classical Chinese poetry and spares the life of a Chinese poet, ${ }^{(26)}$ the ending of the Three-BodyTrilogy also resorts to the literary

23. Liu Cixin, "Ren yu tunshizhe" (Man and devourers), in Shiguang jintou (The End of Time), Shijiazhuang, Huashan wenyi chubanshe, 2010, p. 220.

24. Liu Cixin, "The worst of all possible universes and the best of all possible Earths: Three Body and Chinese science fiction" (Translated by Ken Liu), available at www.tor.com (accessed on 7 May 2014).

25. Liu Cixin, Sishen yongsheng (The Dead End), op. cit.

26. The English translation of "The Poetry Cloud" by Chi-yin Ip and Cheuk Wong is included in Renditions, Vol. 77/78, 2012, pp. 87-113. For an analysis of this short story, see Mingwei Song, "Variations on Utopia in Contemporary Chinese Science Fiction," art. cit. 
imagination as the most powerful manifestation of humanity. An advocate for technology and "hard SF," Liu Cixin nevertheless so romantically and idealistically invests literary imagination with a transcendental faith in hope.

The end of our solar system is the climax of Liu's trilogy. The last monument of human civilisation is being constructed on Pluto, where the main characters (Luo Ji and Cheng Xin) witness the disappearance of the human world. At this moment, all is lost. China's rise, eternal peace on Earth, and all of the most splendid utopian dreams are gone. But it is also from here that Liu Cixin has truly led us to encounter the unknown. His literary imagination transcends obsession with China or concerns with utopian/dystopian dialectics. He directly speaks to the infinity of the universe. His space saga shows the universe as darker than anyone can imagine, but at the same time, as one of his characters says when first entering a four-dimensional bubble in outer space, "Even a little tiny part of it is unfathomable." (27)

Compared with other Chinese science fiction writers, Liu Cixin is the most cold-minded about the limitations of humanity, a critic of humanism and a disbeliever in optimism. Yet, his world is also the most marvellous, with a stirring power of attracting readers to question and explore the unknown, and his narrative displays a profound curiosity about the infinity beyond what we thought we knew. Above the enormous darkness of an immoral universe, there is indeed a light of utopian vision that transcends the interests of nations and peoples and expands on the scope of light years. It is a post-human universe that, contrary to optimistic expectations for realisation of certain ideals, thrives on unpredictably infinite possibilities. Liu Cixin says that he writes about the worst possible universe, but he also leaves us the space for imagination of the rest.

\section{A post-human future}

More than any other science fiction authors coming from China, Liu Cixin, who is by profession a computer scientist, is more interested in exploring the conditions of post-human existence, through which he questions the conventional concepts of humanity in a new age blessed, or menaced, by post-human possibilities. What is the post-human? It at least contains a questioning of the humanist belief in the self-centred position of humanity in the universe. It involves the epistemological shifts brought out by new sciences such as string theory and new technologies such as information technology, artificial intelligence, and biological engineering, which frequently appear in Liu Cixin's novels and stories. Uncertainty and infinity challenge confidence in totality and integrity, and dismantle the rationalism and self-determination that underline the optimistic version of humanism. This paper, however, limits the discussion to only the cultural and ethical effects of Liu's experiment with a post-human image in the context of the post-1989 Chinese cultural changes. I consider the post-human future, which may not necessarily be utopian, an intriguing response to the various symptoms of the problems in contemporary China.

In Liu Cixin's short story "Micro-era" (Weijiyuan 微紀元, 1999), the posthuman "micro-era" is 25,000 years in the future. A world without worries and sorrows, it is populated by youths - only youths, and they will never grow up to adulthood. Actually, they are some tiny, cute, beautiful people, the so-called "micro-humans," who have been genetically regenerated, with their size reduced to roughly one trillionth that of an ordinary human being. These "micro-humans" are the only surviving species after the Earth has been torched by the sun. Their microscopic size enables them to escape the apocalyptical explosion of the sun and later re-emerge as the new rulers of the planet, building cities as small as water drops and creating a monument to the extinct humanity that is as light as a piece of hair. Their era is characterised by "lightness" and "weightlessness," and their sense of anxiety is proportionate to their extremely small seize. Their life is completely carefree and joyous. Correspondingly, they have no burden of responsibilities, no memory of the past, no sense of history, and no necessity for self-development. Living in a sort of eternal carnival, the "micro-humans" are indulged in a dreamy ecstasy of enjoying a childish, innocent, and forever youthful life.

The story is told from the perspective of the last man, or the last so-called "macro-human," who returns to Earth after a 17,000-year long space odyssey searching in vain for another earth. Called "the pioneer" in the story, he is saddened by the total extinction of the human race, but also surprised by what he sees with the aid of a special amplifying technique: a microcosm, a utopia of youth, with paradise-like settlements wrapped in water drops, floating freely on the surface of the Earth. He is warmly greeted by the "micro-humans" and treated as a patriarch, mentor, and leader. The "chief executive officer" (zuigao zhizhengguan 最高執政官) of the future utopian world, a pretty and cheerful young girl elected to office exactly because of these qualities - who actually is not unlike the female leader in China 2185, also called the "chief executive officer" in that novel - engages a dialogue with the pioneer. She informs the pioneer that in her world, melancholia and grief are found only in museums. But after seeing the true sadness in the pioneer's eyes, she is moved to tears, and at the same time thrilled by the electrifying imagination of an older world full of tragic, grandiose, and sublime historical events, which she considers to be so beautiful, almost like an idyllic romance. However, she and her people will never truly appreciate that sadness, for their feeling of sadness is groundless and elusive, and during their lifetime, they will only "grow more and more childish, become happier and happier." (28)

This story reminds me of Lu Xun's allegory about the ancient hero who "burden[s] himself with the weight of tradition and shoulder[s] up the gate of darkness," giving "unimpeded passage to the children so that they may rush to the bright, wide-open spaces and lead happy lives henceforward as rational human beings." (29) But in Liu Cixin's story, the pioneer does a simpler job than that required for the ancient hero. He is confronted with two choices: should he revive the human genes stored in his interstellar ark so the ancient "human" civilisation could be restored? Or should he just quietly accept the demise of his generation (or species) and let the child-like "micro-humans" continue to prosper, without ever burdening them with the knowledge of the eventful, tragic history of the "macro-humans"? After only a second of hesitation, he chooses to vaporise all the human genes he carries from the older world and keep the "micro-era" untouched. Thus the pioneer ends the history of the human race and celebrates the arrival of a post-human utopia.

Contextualised in China's cultural changes since 1989, this story of the "micro-era" predicts Guo Jingming's 郭敬明 recent cinematic representation of a less scientific "tiny time" (xiao shidai 小時代) that speaks volumes to the lack of sorrow and memory in China's "new age." "Micro-era," a technologically positive image of a post-human future for Liu Cixin, and the "tiny time," a hedonist version of a post-socialist present for Guo Jingming and

\footnotetext{
27. Liu Cixin, Sishen yongsheng (The Dead End), op. cit., p. 195.

28. Liu Cixin, Weijiyuan (Micro-era), Shenyang, Shenyang chubanshe, 2010, p. 100.

29. The translation is T.A. Hsia's. See Hsia, The Gate of Darkness, Seattle, The University of Washington Press, 1968, pp. 146-147
} 
his fans, may both serve to terminate the enlightenment ideas concerning development, progress, self-cultivation, and psychological growth, the very core values of humanism. The post-human utopia of youth, like the one imagined by Liu Cixin, is both a culmination of and a counterpoint to the over-determined symbolism of the "youthful" image of modernity through simultaneously exaggerating its self-affirmation and dehumanising its selfidentity. If this story remotely echoes Liang Qichao's solemn call for a "young China" at the beginning of the twentieth century, its bright, cheerful imageries, created at the beginning of the twenty-first century, may have emptied the very content of its political interpellation while splendidly keeping its dynamic form.

Such a cultural phenomenon may correspond to a paradigm shift in the political engagement of China's youth since 1989. In a 1999 literary review of the fictional writings of a group of new authors born in the 1970s, a generation I belong to, I commented on a new phenomenon appearing in the literary depictions of youth, which I named beidong chengzhang 被動成長 (passive growth). In stories by authors such as Ding Tian 丁天 (b. 1971) and Zhou Jieru 周潔茹 (b. 1976), loss of political innocence, failed idealism, and a common cynicism are all contextualised as part of a social conspiracy (in the unspoken post-1989 political environment) that constructs subjectivity without giving it much free space. Unlike the earlier generations, these authors did not show a clear intention of resisting this conspiracy, except through mockery and self-mockery. The two most popular authors of this generation, Wei Hui 衛慧 (b. 1973) and Mian Mian 棉棉 (b. 1970), concretised the youth figure of their generation as a reckless consumer. Through their national bestselling debut novels Shanghai Baby and Candy, they paved the way for a new type of "youth literature" that emphasised a hedonistic, escapist tendency in the characterisation, reducing the conflict between self and society to a self-exhausting pursuit of pleasures. Anxiety ends, and growth becomes a passive process enabled by the pleasure-seeking instincts sharpened by a combination of political indifference and a ready surrender to commercialisation. ${ }^{(30)}$

Forgetting "the macro-human" age in Liu Cixin's story, and the self-indulgence in Guo jingming's "tiny times," both point to cultural symptoms of the post-1989 era in which the forgetting of history is sanctioned by economic development and political indifference. Liu Cixin wrote "Micro-era" in 1999, and his vision of the post-human utopia of youth became "reality" in Guo Jingming's "Tiny Time" trilogy. Liu's story brilliantly comments on the emerging trend in a hedonist celebration of the new age. Through his literary imagination, Liu creates the "future" of contemporary China.

The future offspring of humanity, as depicted in Liu Cixin's "Micro-era," are a generation of xinrenlei 新人類 (new human beings - the same word being used to name the generation after Wei Hui and Mian Mian), who enjoy a life full of pleasure and happiness but who have completely lost historical consciousness. An apocalyptic story, it nevertheless points to a future that evokes a seemingly sweeping optimism. The pioneer sheds happy tears as he looks at the cheerful faces of humanity's micro-children - do we not all hope that our descendants will live happily ever after? Would Lu Xun be satisfied with such an ending, while he ends his "A Madman's Diary" with a call to save the children? Will these post-human youths who never grow up be more successful than us, the so-called "macro-humans," burdened as we are by morality and historical consciousness? Liu Cixin's story does not hide the hideous side of human extinction: the paradise is built upon complete oblivion to the abysmal darkness of all past traumas and tragedies they are a new generation born after the end of humanity's history. Is this post-human future a blessing or a betrayal for those who are acutely aware of certain circumstances of China's historical changes over the past several decades? But who are we? How are we constructed as "humans" - with memories and regrets of our troubled human condition?

\section{Coda: The ancient songs of earth}

Six hundred fifty light years away, a bright star (31) keeps broadcasting songs - powerful, militant, and sublime songs that attract a human spaceship to approach it and explore its history. Bao Shu 寶樹 (b. 1980), a young writer who rose to fame by composing a pastiche sequel to Liu Cixin's Three-Body Trilogy, first published this story, originally titled "Star Songs" (Xingge 星歌, 2012), on the Internet. When the story was published later as the title story of his first short story collection The Ancient Songs of Earth (Gulao de diqiu zhi ge 古老的地球之歌, 2013), what was changed was not only its title, but also what the explorers discover in that star. In the online version, "star songs" are none other than "red songs," the patriotic revolutionary songs of the Mao era. In the print version, they are changed to patriotic revolutionary songs from the Stalinist era. These songs are broadcast by nanorobots that fell into the depth of the star centuries ago. It is both astronomically and politically a "red star." The explorers, members of a posthuman, post-revolutionary, post-socialist generation who no longer know anything about a socialist state that once upon a time existed on planet Earth, are all deeply moved by these heart-stirring songs. They cannot stop listening to these songs, and a cult of "red songs" begins to emerge. But what happens is not just the birth of a chorus, but an alteration of the entire fate of the universe. The A.I. system that controls the spaceship is converted to the whatever-ism these songs spread. She (a female A.l., that is) crashes the spaceship into the star and causes its explosion into a supernova. The concert of revolutionary songs begins to rock the entire universe. "This is the final struggle / Let us group together, and tomorrow / The Internationale / Will be the human race." (More accurately, "the Internationale will be the post-human.") The song is collectively sung by the nanorobots that reproduce themselves infinitely. ${ }^{(32)}$

Bao Shu's story can be read as a post-human narrative like Liu Cixin's "Micro-era," but its strong political implication forms a counter-balance to Liu's technological optimism. The unexpected discovery of the "red star" and the dissemination of the "Internationale" by the A.I. nanorobots to the entire universe may well represent, ironically, an ambivalent version of the historical determinism that dominated Chinese utopianism in the earlier age. Bao Shu smartly keeps the tone of the story seriocomic. In a profoundly comical or paradoxical way, it reminds us of a bizarre mixture of nostalgia and futurism as a pair of angels or demons in the shaping of the utopian/dystopian vision in the new wave of Chinese science fiction.

\footnotetext{
I Mingwei Song, Associate Professor of Modern Chinese Literature, Department of East Asian Languages and Cultures, Wellesley College.Email: msong2@wellesley.edu.

30. Song Mingwei, "Zhongzhi jiaolü yu zhangda chengren" (The end of anxiety and growing up), Shanghai Wenxue (Shanghai Literature), September 1999, p. 9.

31. The star refers to Betelgeuse, the ninth brightest star in the night sky

32. Bao Shu, Gulao de diqiu zhi ge (The Ancient Songs of Earth), Beijing, Xinxing chubanshe, 2013, pp. 126-162.
} 